\title{
Operationalizing Interaction between Firms and Regions
}

\author{
Ricardo Correia ${ }^{*}$, Carlos Brito ${ }^{2}$ \\ ${ }^{1}$ Polytechnic Institute of Bragança, School of Public Management, Communication and Tourism, Mirandela, \\ Portugal \\ ${ }^{2}$ School of Economics, University of Porto, Porto, Portugal \\ Email: "ricardocorreia@ipb.pt, cbrito@fep.up.pt
}

Received 22 June 2016; accepted 31 July 2016; published 3 August 2016

Copyright (C) 2016 by authors and Scientific Research Publishing Inc.

This work is licensed under the Creative Commons Attribution International License (CC BY). http://creativecommons.org/licenses/by/4.0/

(c) () D Den Access

\section{Abstract}

Regions are very different as they contain an amalgam of different resources shaped by a diversity of actors. In some extent, they are the result of interactions of different actors that can be located either inside or outside them. Firms are one of the actors that assume more relevance for the regional configuration. Indeed firms have a capacity to act beyond any regional boundaries and a successful firm can "infect" positively the regional dynamics. But the opposite influence is also true. The regional configuration may have impact on the strategic action of firms. The interconnection between firms and territories is thus a key issue for the understanding of the development of both businesses and regions. However, the interactions between firms and regions have not been sufficiently explained. In this context, the purpose of this paper is to clarify the bidirectional influence between firms and regions. Taking advantage of the emerging literature of relational geography and industrial network approach, a model aimed at providing a better understanding of this mutual influence was developed. We find that the lack of relational compatibility can limit firms' effects on the region. Similarly, the influence of the region on firms' performance also depends on this compatibility and on the specific characteristics of the business actors.

\section{Keywords}

Networks, Regions, Regional Development, Interactions, Relational Geography, Firms

\section{Introduction}

Limitations associated to the traditional stand of economic geography and clusters' theory, mainly focused on a conglomeration of firms within a close geographical space and based upon a list of material resources that should "Corresponding author. 
be made available to the regions, have provided ground for a new trend within geography that reinforces the interactive and relational component of regional development. This relational geography modifies the understanding of regional dynamism and puts the essence of regional economies within the dense interaction between diverse actors [1].

Under this perspective, a network point of view seems particularly appropriate for the understanding of the relational space because it allows us to pinpoint various interactions between actors located in diverse regions [2]. Whilst assuming that endogenous factors of regions are necessary for their development and that regional features influence, diversely, the actions of firms, this approach to economic geography also recognizes that these factors and features are by themselves insufficient to generate regional growth. They need to be activated and connected with specific networks that usually involve multiple scales and diverse actors. When they interact, they cut through multiple regions.

This new stream of research on relational geography has progressively put in evidence the role of firms for regional development. In fact, due to their interactions, firms can become one of the most relevant actors in the current regions' configuration. They create regional characteristics in the way they train workers or in the way they insert know-how in the region where they are implanted, and while interacting, they manage to bring to close contact different regional contexts [3] [4]. A firm can be located relationally almost everywhere its interest meets the interest of another actor, hence it does not necessarily require physical elements to be present and active in a specific region. The notion of global production networks as defined by Coe et al. [5], taking advantage of the multi-scalarity provided by network configurations is especially useful to understand the interconnection between multiple scales operated by firms. The suitability between regional, institutional, social, cultural structures and firms networks patterns may play a substantial role in the introduction of a local region in an upper-scale reality and in the benefits that the region can obtain. At the same time the GPN configuration can also be influenced by the concrete contexts it found in the multiple regions it cut trough [5] [6].

Despite the significant advances which challenging the traditional vision of the economic geography, the interactive process firms establish with regions is not satisfactory explained [4] [7]-[9]. Particularly, the relational approaches do not sufficiently describe the business organisation and the fundaments of their interaction. Indeed, one of the questions frequently asked and not yet properly answered, is: "how do firms interact with one another and what are the consequences for localised processes and structures?” ([8], p. 138). Furthermore, as far as the network approach is concerned, and despite numerous references and the relevance attributed to networks by the relational geography, seldom are such references made in an explicit manner [10]-[12]. "Much of the use of networks in economic geography has been rather selective, often metaphorical and little formalised” ([13], p. 620).

The industrial network approach developed by the IMP Group [14]-[17], has for a long time clarifying firms' interaction and strategic action, as constituting one of the most important factors for regional dynamics, although it is not sufficiently explained by relational geography. We can also find a strong clarification in inter-organisational networks in this conceptual field, which result rather useful to the operationalisation of this concept in relational geography. In addition, research coming from the industrial network today is so extensive that it surpasses the limits of firms' interactions that were at the centre of its origins. Indeed, valuable contributions to the understanding of the regional dynamics recently appeared from authors related to this approach, thus revealing a strong compatibility with the relational geography fundaments [18]-[26]. These complementarities and related understandings coming from these different approaches reinforce the relevance of interlinking them in order to generate knowledge about the reciprocal influence between firms' action and regional dynamics.

The purpose of this paper is to develop a conceptual model aimed at operationalizing the dynamics and interaction between firms and regions. We focus on the interconnections between firms' pillars for interaction and the consequences they reflect on the regions' structure while considering the regions particular features influence on the firms' interaction. For that we take advantage of the complementary contributions coming from relational geography concepts and the industrial network approach of the IMP Group. They criticise the generic and mechanic vision implying that the development and regional dynamics depend on general factors of success replication. Indeed we go further with a conceptual discussion from which a number of propositions integrated into a proposed model result, thus trying to capture how firms' strategic action is reflected upon the regional dynamics and structure and how such factors affect the firms' strategic action.

The paper is structured as follows. Section 2 addresses regional studies under the perspective of the relational geography approach that challenges the traditional vision of the regional management and economic geography. The third section outlines the process of firms' interactions from the perspective of the IMP Group. The recent 
industrial network approach contributions to the regional dynamics that reveal a strong affinity with the relational geography fundaments are also detailed in this section. In the fourth section, based on the previously mentioned theoretical approaches, we advance into a discussion based on three propositions, which deal with the reciprocal influence between firms and regional dynamics. These propositions are then translated into a theoretical model aimed at answering what has been detected as lacking and that can constitute a base to reinforce the knowledge on the relationship between firms and regions which remains relatively generic. The last section presents the conclusions as well as suggestions for further research.

\section{Relational Geography}

\subsection{Regions as Networks of Relations}

The concept of region has evolved due to the inclusion of relational elements in its characterisation, and this has originated what is currently known as "relational geography" [2] [4] [7] [8] [27]-[31]. Relational geography represents "a theoretical orientation where actors and the dynamic processes of change and development engendered by their relations are central units of analysis" ([28], p. 109). It came about as a result of traditional approaches of the economic geography unability to explain micro-dynamics which support different means of economic coordination [28]. The regions in such (traditional) approaches are considered as economic actors, and the real actors (people, firms and institutions) with the capacity to change and mould the region are often ignored. The factors explaining the decision-making process for localisation are physical distance and cost reduction.

The relational approach is based upon the interactions occurring at a micro-level because of diverse regional processes. Space is analysed in a continuous relationship with economy and also in sharp contrast with previous positions that take it as a separate entity which is truly independent from economic actions [4] [8] [30]. Thus, "economic actors and their action and interaction should be at the core of a theoretical framework of economic geography" ([8], pp. 123-124), since the "economic action and interaction are the central object of knowledge in the analysis" ([8], p. 125). The conceptual basis for relational geography is based upon an institutional perspective [32] [33]. In such a scenario, actors' actions and objectives are not previously defined in order to conform to maximisation and rational logic. Instead, they are moulded by specific social contexts of the area where they are located in and which shape their actions. "We cannot understand economic geographies outside a set of formative, if perpetually changing and challenged, social relations” ([34], p. 339). Many regional developmental conditions are institutional and cultural. This is often called the relational capital [29] [35] and is made up of social and economic relationships in a given geographical space [35]. The relational capital of a certain region is often one of its most important sources of success due to its inimitability [29].

There are three consequences of actions and economic interactions in relational conceptualisation [7] [8]: 1) On the one hand the relevance of the context-agents are inserted in specific contexts of social, cultural and institutional relationships which create formal and informal relationships. On the other hand, theorists of relational geography try to frame the firms' actions within a specific space context and time framework [11]. 2) A pathdependence - a geographic place has "a memory which shapes the path of subsequent developments” ([36], p. 603). Past decisions shall influence future paths. 3) Due to this contingency - the importance of the past-economic processes cannot be predetermined, since strategies are both individual and collective strategies are contingent and may alter the already existing structures. These characteristics imply that the general laws of economic action do not exist and thus the generic policies of regional development cannot be developed as an ever-successful recipe that works every time the ingredients are available (such as postulated in the cluster theory). Instead, they must be based upon an evolutionary and contextual understanding of economic action [7].

\subsection{Firms as Regional Actors}

Within the context of relational approaches, firms are noteworthy regional actors [3] [8] [37]-[39] because decision-making at a firm level moulds the regions and it development process [40]. Consequently, to understand the development trajectory and regional dynamics, we need to focus on firms and their interactions. During their activity, firms inculcate characteristics in the regions that welcome them and, in result; resources from various origins establish contact. Simultaneously, their activity is influenced by regional configurations. Acknowledging this role played by the entrepreneurial actors, relational geography proposes an approach between spatial and economic 
management. Therefore space and economy are interlinked and cannot be analysed separately [4] [8] [30].

The relationships between firms and the region where they are located in are reciprocal [13]. Such reciprocal influence is well reflected on in a paper by Schoenberger [39]: "The Firm in the Region and the Region in the Firm”. Such relationship reflects the way in which firms' specific characteristics mingle with the specific characteristics of the regions.

However, the interactive relationship between firms and regions is not totally explained although the firm is pinpointed as the key element of the relational space [8] [9]. Existing publications reveal that one "has tended to have a naive view of the spatial character of firms and of the ways in which firms relate to territory" ([40], p. 355). This approach does not entirely describe the firms' organisation nor does it specify the basis for their interactions. It is imperious to possess a broader understanding of the processes which lie beyond the interdependent actions that develop at a micro-level. In fact, there are some challenges to solve in order to clarify the obvious relationship between firms and regional dynamics. One of them is how to make theoretical connections between micro events at a firm level and their spatial repercussions normally only observable at a regional level [41]. Relational geographers have been progressing in this aspects in order to better understand firms, looking at them as relational and specific constructs, made up of social actors and therefore very far way from a mechanistic black box [3] [9], however it is necessary to go beyond this assertion and "clarify exactly what this social construction of the firm is about” ([3], p. 311) relating it’s configuration with regional dynamics.

\subsection{Networks and Regions}

Another structural characteristic of the relational geography approach is that it does not assume local, national or global spheres as different components from social action. Indeed, it promotes a relational understanding of each of those as a "nexus of multiple and asymmetric interdependencies among and between local and wider fields of action, organisation and influence ([42], p. 153). This point of view makes the network perspective an excellent way to approach the relational space. The main advantage of a network approach is that it can transcend all those scales without falling into the conceptual trap of preferring any one of them [2]. Geographical lenses can be used to allow focusing on specific localised representations of the economic processes [8] taking into consideration that any scale is co-maker of a dynamic and complex geographic reality in its whole [43].

Regions tend to progressively transform themselves and become part of a global network, thus witnessing connections and distant influences from multiple actors [27] [44] [45]. Local economies reflect the policies and strategies of actors located in various regions [46], and the specificities of the firms, regions and other actors in interaction [4] [5] [47]. Then, it becomes harder to distinguish between local and global relationships since there is a growing interdependence between them [48]. The global production networks (GPN) concept defined as "globally organized nexus of interconnected functions and operations by firms and non-firm institutions through which goods and services are produced and distributed" ([5], p. 471) is a useful perspective to capture the dependence of regions upon different connections as it recognizes that regional development depends on a multiscale process of interactions, influences and interdependencies [5] [6] [9].

Both dynamics and interactions associated to a region are referred to by the relational approach as being essential for their development. They are "the tangible and intangible flows between the actors function as a blood circulation system in the region, enabling the system to meet the changing needs of the business environment" ([49], p. 207). The regions need their firms to have privileged links with internal or external actors capable of providing them with their dynamics. External sources of knowledge are especially important to stimulate growth within that region [50].

A region must be linked to the outside world in what Owen-Smith and Powell [51] call pipelines to avoid declining due to entropy [52]. Such a concept is linked to knowledge originating in the outside world through a relationship between its diverse actors. However, when a region is linked to global production networks, such a fact does not automatically warrant a positive development since local actors may generate value in a manner that does not maximise the economic potential of that region. Local actors in a region may not be able to keep much of the value therein created [5]. Local firms must develop the capacity to assimilate the information and to efficiently apply it in order to create value. Cohen and Levinthal [53] call the capacity of a firm to identify, assimilate and exploit the knowledge deriving from its surroundings "absorptive capacity". It is also important to reflect the ability of certain given locations to potentiate or to appropriate the value created there and acknowledging that "it is one thing for value to be created and enhanced in given locations, but it may be quite another for it to be captured for the benefit of those locations” ([6], p. 449). As such GPN propose the concepts of value 
enhanced and capture value in given locations.

In all these perspectives it is obviously the highlighting of the interaction between various scales for the production of regional effects, which gives the network approach a crucial importance in relational geography. However, despite the excellent contributions of authors such as [2]-[6] [9], the concept of network applied to local dynamics still needs to gain better operationalisation and depart of an application domain that is still largelky of abstract nature. This need for the operationalisation of networks links to the need for more detailed understanding of business actors and their interaction processes that underlie influences occurring at different scales. In fact, the GPN recognizes the dynamic influence between firms and regions, clearly identifying the need to clarify the performance of firms to understand development at various scales: "we need to study what firms do, where they do it, why they do it, why they are allowed to do it, and how they organize the doing of it across different geographic scales” ([6], p. 438). Yet, the specificity of the firms and the reasons of their strategic performance are not detailed enough to overcome what the very approach recognizes as fundamental: the specificity of the firms [9].

To overcome these limitations we need to connect all the significant contributions coming from relational geography and GPN with more knowledge about the firm, that recognizing it as a social and specific construct could also clarify the basis for it strategic action and interaction that are also in the basis for their network configuration involving these elements with regional structures and development.

The industrial network approach, to be analysed next, does show a simultaneous notable adjustment and strong affinity with the characteristics conferred to the regions by relational geography, which has, for the past thirty years, focused on the study of the relations and interaction processes between firms. The interrelation between these theoretical orientations can make both gain momentum and more important than that, help to understand the interaction phenomena between firms and regions more effectively.

Indeed, the similarities in the guidelines of GPN and the positions associated to the industrial network approach are evident. This compatibility is even more relevant when these approaches were developed independently without any significant interaction between them. The approaches of industrial networks do not initially have any geographical claim, before focusing on the interaction process and relationship between companies. As a result of the accumulated knowledge in what the processes of interaction and relationship are concerned, the industrial networks approach explains the nature of relationships and the cognitive components associated with the business interaction. This approach has positioned itself as especially appropriate to clarify the strategic action of firms and illuminate the black box that still characterises them, thus supplementing the relational positions of geography and GPN.

\section{The Industrial Network Approach}

\subsection{Markets as Networks}

The approach of markets as networks is based on organisational theories such as the studies undertaken by Cyert and March [54], which consider organisations as alliances, Katz and Kahn [55] who contribute to this understanding by focusing on the eminently open nature of the organisations and Pfeffer and Salancik [56] who trace the elaborated social environment where organisations operate.

Although based on the studies addressed previously, the development of such approach owes much from the research efforts of IMP (Industrial Marketing and Purchasing) group authors on inter-organisational networks. This stream of research was created in the 1970s, and its seminal studies were developed especially at the Swedish universities of Stockholm and Uppsala. Its research techniques spread to other research centres mainly in European countries such as the universities of Lancaster, Manchester and Bath in the UK [15] [57]-[59] and later to North America [60] [61].

The industrial networking approach begun developing as "a tool to investigate relationships that connected dyadic counterparts not only to each other, but also to a larger structure” ([62], p. 30): the network. This is characterised by the interactions that evolve from relationships established between the different actors who have access to resources and develop activities [63].

\subsection{The Interaction Process}

One of the most important research objects in industrial network research becomes the long-term relationship, its origins, characteristics and effects [64]. The interaction process is divided into episodes which involve the 
processes of exchange (of goods and financial, information and social services) and relationships that occur with the repetition and institutionalisation of episodes [65] (Figure 1).

Relationships often involve multiple interactions, which emphasise the social component [66] and through these various interactions that take place in time, predictable patterns of activity will be formed. The links between actors become institutionalised on a long-term basis concerning a set of rules, which reflect past events [65]. Past interactions have a key role in the current relationship "the past is projected into the future" ([67], p. 24). Actors "learn" to relate to each other and "learn" with the relationships [68]. The context of the dyadic relationship at moment two (Figure 1) will necessarily be different from the existing context at moment one. So, the interaction process appears contextualised in the relationships between the firms [17].

The choices of future relationships largely depend on their current relationships, which in turn have depended on past relationships and their resulting experiences [69]. There is a historical track that affects relationships. Thus, the interaction approach understands relationships as important in themselves and as predictors of future behaviour [17].

Interaction is also one of the main ways used by actors to generate new knowledge [70]. The interaction process provides access to other relations and with them access to new organisations and resources [71] [72]. "An important way to learn is through others" ([68], p. 443). In a dyadic relationship there are three groups of factors that can influence such learning context: the characteristics of the two parties involved, the type of relationship established and the context of the relationship in itself [68], thus defined as "a set of connections directly related". Therefore, "the larger the connections in a relationship, the greater the opportunities to learn (...) because there are more interfaces where learning can appear” ([68], p. 445).

\subsection{Firms' Strategic Action}

A clear-cut rupture between the positions that defined borders between organisations and their environment is also a common characteristic for this approach. Due to the relationship's links, the organisations do not adopt the environment in an unchanged manner, but as an element with which they interact in a specific way [73]-[75]. Firms far from acting in an atomistic manner have an identity [76] and belong to a specific social and economic environment. Organisations' results largely depend on how and with whom they interact [74] [77]. As a result of the interdependence between the units in study [78], the behaviour of a firm should be understood in the global context of their relations with others [79].

A firm alone cannot build up its strategy [74] [80] [81]. It does not confine its activities to its physical borders and has difficulties in defining its own borders [82], since such a strategy derives from interactions and is indexed to relationships. In this manner, the interactions and the relationships become as important, or even more important, as management, in order to influence the firm's strategy [74]. It is of the utmost importance to invest in relationships and the strengthening of these so that firms are able to strategically perform and adjust most of their competitive advantages to a proper alignment with the surrounding environment [83].

In such a perspective, strategy is defined by the way "in which a firm achieves exchange effectiveness in relation to other firms in the surrounding network that is, how a firm initiates and reacts to changes in the network in such a way that the firm keeps on being valuable to the network” ([84], p. 409). The strategy is, thus, the result of a joint process where many firms take part [85]. Consequently, most strategic activity revolves around influencing others and managing relationships within a context built upon interaction.

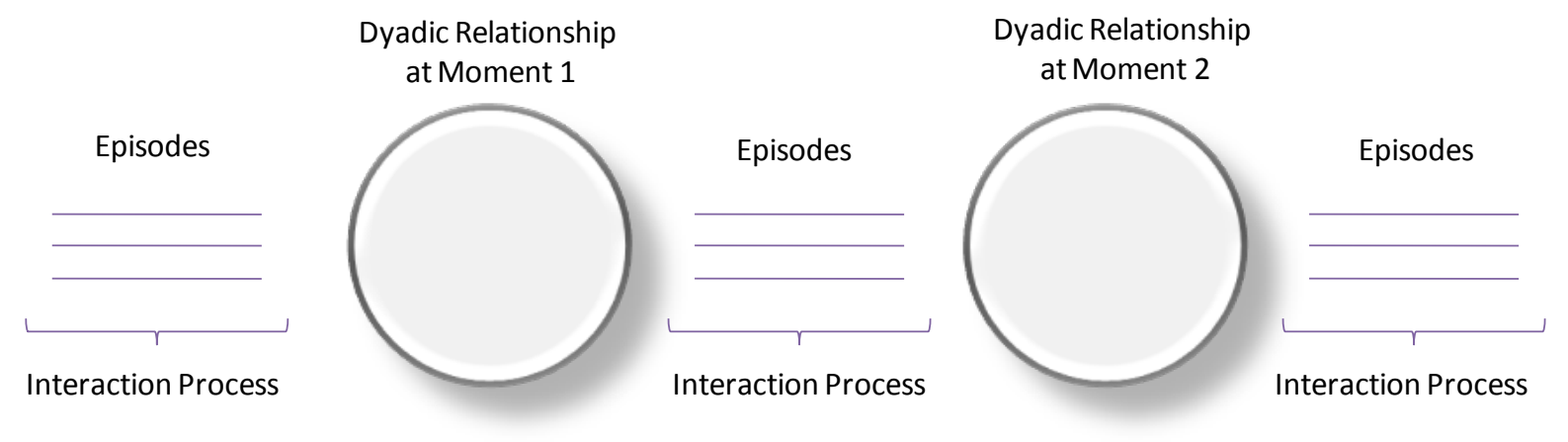

Figure 1. The interaction model. Source: Häkansson ([65], p. 24) (adapted). 
We can identify three elements that structure the firms strategic action in a network perspective: network theories, their position in the network and their resources [86]. Because they influence the focal firm, due to connectivity associated to relationships, they also have the capacity to origin changes in the networks that the firms occupy. These elements are the result of firms' interaction and evidence that the strategic action is not a matter of an individual focal firm but results from their interaction in the network [87].

\subsubsection{Network Position}

Firms do not prosper only by their individual effort, they also depend on the relationships maintained with others and of the direct and indirect relationships' nature developed with them [88]. Actors who interact with a firm give it a position that depends on the set of relationships it has [86]. Any organisation occupies a position in the network. Firms' network position is, however, a relative concept that is externally endorsed. Thus, there will not be two equal positions given by different actors to the same focal organisation [74].

A firm network position can be understood as a resource, an intangible asset that influences its action's capacity and simultaneously, as any resource, supports and restricts its strategic action [17] [88] [89]. According to this perspective, Turnbull, Ford and Cunningham ([17], p. 47) define position as "the company's relationships and the rights and obligations which go with them”. Low ([90], p. 191) relates the concept of position with power defining it as “a location of power to create and/or influence business relationships". The position a firm occupies depends on the relative importance it can attract from the remaining actors and this involves a relational process to progressively match the firms' resources and activities to the requirements of other firms in the network [90]. Therefore "a crucial aspect of any firm's positioning strategy will be to form relationships to strengthen its position, in one or more networks” ([90], p. 191).

The development of new relationships by the firm change the way its identity is perceptible in the network: i.e., its position. Due to relationships' dynamic character, firms’ position is not definitive, and constantly changes with time [67] [91]. As all the firms are connected and the positions are relative and conferred by each individual actor, the change of a firm position will affect the position of other firms [90]. Thus, positions may be positively or negatively connected, and the strength of one actor position may, according to the situation, conduct to the strengthening or weakening of the position of other firms [86].

According to Johanson and Mattsson [92], the concept of position reflects the situation of the actor related to four components: 1) the identity of the connected firms, 2) the firms' role in the network, 3) the importance of each firm in the network 4) and the strength of business relationships.

Turnbull, Ford and Cunningham [17] suggest that in addition to the portfolio of the firms relationships, the analysis of the position requires the observation of additional resources constructed through interaction, such as 1) the access to resources of the counterpart, 2) the reputation (which is dependent on the experience of other network members), 3) and the expectations regarding their behaviour.

\subsubsection{Network Theories}

Due to the broad network magnitude, the actors have only a limited cognitive capacity of the networks they belong to. They are restricted to a horizon, which confines the reality they know. When the interacting firms have differentiated network horizons, the visualisation of new opportunities for interaction is vastly improved [25]. To overtake such limited knowledge of the network, the firms create diverse cognitive structures depending on the interactions occurred in the network that result from the interpretation of past experiences [86] which have the capacity to shape their actions in the future. These network theories are described by Mattsson ([63], p. 417) as "the actor's set of systematic beliefs about market structure, processes and performance and the effects of its own and others' strategic actions". They not only affect the strategic action of the actor which formulate them, but also that of others as they can be transmitted to counterparts [86] [93]. "Interaction with others is a major source and factor in the continuous adaptations in the cognitive structures guiding their behaviours” ([67], p. 26).

The network position also influences the network theory considering since this is largely based on information resulting from relationships between actors [86]. Through the relationships, maintained actors exhibit to counterparts their theoretical formulations, and depending on their position have the capacity to influence them. Thus, changes in actor network theories, and consequently in the dynamism associated to the network, can occur, and result from the emergence of new relationships or from the interactions of already existing ones.

The concepts aimed to introduce theoretical formulations about actors' subjective perceptions about the net- 
works have been evolving, and new terminologies as ideas [94], network pictures [64] [95] and network framings [96] [97] emerge. All the terminology developed from the network theory concept refers to actors' subjective formulations. They reflect past experiences and occurrences and are linked to relationships, constituting a referential mental support for the actors' strategic action.

\subsubsection{Resources}

An extensive range of literature about firms' resources emphasise the internal and homogeneous component of resources, understanding it as something that is mainly processed within the firm [98]-[100]. In this perspective, firms competitive advantage source is based on what happens inside their physical borders, due to the particular characteristics of the resources they contain [101].

The industrial network approach is sceptical about the direct control over resources a firm can obtain since a substantial part of the resources available to the firm are under the direct control of other actors and can only be accessed by the interactions and relationships in the network [77] [80]. This position concerning the external component of resources addressed by the industrial networks approach is mainly based on Penrose [102], Richardson [56] [103] and Loasby [104] [105] contributions.

Araújo, Dubois and Gadde ([106], p. 498) refer that "no company controls all the resources they require”, and the competitive advantage of the companies is not only inside the borders of what it has and controls, but in all the interfaces it develops with others [107]. Resources are used together and in interaction with other resources and their features are created through these combinations [62]. Nevertheless, in order to act, firms need to know how to interact, connect and make their resources grow. The external competences' access does not make itself available automatically, it requires a specific range of competences and relational efforts to come out [108].

This is how the IMP holds its position, thus considering relationships as resources: "relationships are not only tools to save resources or to create new roles to them, but are also important resources in themselves” ([62], p. 30). They are the source through which you access the knowledge and other strategic resources [88]. This analysis highlights the importance of the relational and external dimension of resources. Some vital resources may not be physically within the organisation, yet it is essential that there are internal resources that allow access to them [16] [109]. These access resources work as a recruiter of external resources, depending on the relationships and extent of the firms' position in the network.

\subsection{The IMP Contribution to Geography}

The industrial network approach has broadened its initial focus on interaction processes of the firms, extending its field of analysis to the areas where this interaction process may have influence. Thus, being business actors a major player of the regional dynamics, the contributions of authors linked to the IMP arises naturally, framed in various geographical scales and generating a link between these studies and geography.

The regional understanding resulting from these studies is similar to those coming from the relational geography approaches: greatly dynamic, interactive and relational. Apart from the attribution of a dynamic characteristic to the regions, these authors also recognize the relevance of history since they consider that regions should not be seen as individual entities merely linked at a distance with other geographical entities. Regions have different historical paths and dynamics which have diverse inflows and outflows that are capable of changing the relationships and dynamics within such areas [23] [26].

Regional features are considered "as something that not only affects the individual firm, but also the way the individual company interacts with other companies" considering that "the companies' interaction creates the place" ([21], p. 231). Thus, the social and institutional relationships characteristics that develop and originate in a regional context are unique, inimitable, and affect the potential and attractiveness of the region where they are located.

Regional dynamics depend on a network of connections resulting from the structure of relationships between firms since they are all involved in networks that outflow the regional boundaries. Hence, the dissemination of knowledge and network learning derives from a relational pattern and not only from physical proximity between actors [24]. Geographical proximity is just a mere factor that may be able to influence the relationships and network patters. Other factors capable of influencing the relational pattern are social, technological and organisational proximity [110].

Regional interactions are based on the interaction between the various actors belonging to those regions. For this to happen, interaction needs some form of relationship which becomes an important bridge to overtake spa- 
tial distances as well as cultural and competence distances [18]. These may link various regions and create regional network configurations. In this manner, a region may be intimately dependent upon developments that are happening in another and vice versa [19].

The main idea is that regions and firm resources mutually interact affecting each other [18] and in fact the power of interaction in order to promote regional development is stressed independently of firms location [26]. In short, the industrial network approach proposes a vision where network position, network theory and firms resources are more important than their mere location for the strategic action and the choice of counterparts. The regional dynamics are created according to the way in which firms value their resources, in how they add/accumulate value and in how they relate to each other (i.e., by what they do and how they do it) and not merely by existing in a certain space.

\section{Operationalizing the Interaction between Firms and Regions}

\subsection{Propositions}

The structural features resulting from the application of the concepts of the industrial networks approach were already present in the relational chain of geography. Although the approaches by relational geography and GPN are gaining importance within studies related to regional development, the specific features of firms and its strategic actions are not analysed in depth. Much of the understanding about firms is still based on generic concepts such as lead and supplier firms [9]. Alongside, the essence of the business interaction resulting from several cognitive processes and interactions developed in the interorganisational networks that are reflected internally on the firms' decision-making are largely neglected. The Industrial Network approach provides a description of the firms' interaction and relational processes essence compatible with the principles of the relational approach.

Although the potential for the interaction between space and companies explanation revealed by the industrial network approach, it is not yet sufficiently developed and focused on regions in a way that makes it possible to understand how that interaction occurs. There is no sufficient explanation on how changes resulting from the firms' strategic action reflect on the dynamics and regional structure. This consequently gives origin to an opportunity: to conceptually relate the contributions of the industrial network approach to the structural principles of relational geography in order to clarify the interaction between firms' action and regional dynamics. As a result of the literature review, we developed three propositions with that goal in mind. These propositions are integrated into a proposed model that attempts to deal with the mutual influence between firms and regions.

\section{Proposition 1}

Firms' strategic position and actions affect the structure and dynamics of the regions where they are located.

\section{Proposition 2}

Industrial networks affect the structure and dynamics of the regions where their firms are located.

\section{Proposition 3}

The structure and dynamics of the regions affect the firms' strategic position and actions as well as the industrial networks.

\subsection{Conceptual Model}

\subsubsection{Firms}

By recognizing the specificity of business actors [16] [76] [80] and its importance to regional dynamics [3] [8], [37]-[40], the focal firm was placed on the origin of the proposed model, thus emphasising its theory and position in the network as critical to its strategic performance (Figure 2).

The network theory, formed by a set of beliefs and perceptions of the actor "in relation to the structure, process and market performance, the impact of their strategic action and the performance of the others" Mattsson ([63], p. 417), is clearly subjective and specific of the focal actor. This theory clearly leads the decoding idea that the firm makes of the behaviour of the surrounding actors, and therefore has a strong influence on its strategic action and consequently on the relationships established by the business organisation [67] [86].

Depending on their relevance, their role in the network and the counterparty with whom they relate, the firms obtain a position in each of the inter-organisational networks they integrate [17] [92]. The firm's position is then understood as the result of its relationships, rights and obligations [17]. Depending on this position, the firm will have access to third party resources, essential to value its own internal resources and development of activities. As such, the firm's position reflects the access resources of the focal actor, thus reflecting the ability the firm has to access the resources of other organisations and also the importance ascribed to it in terms of that 


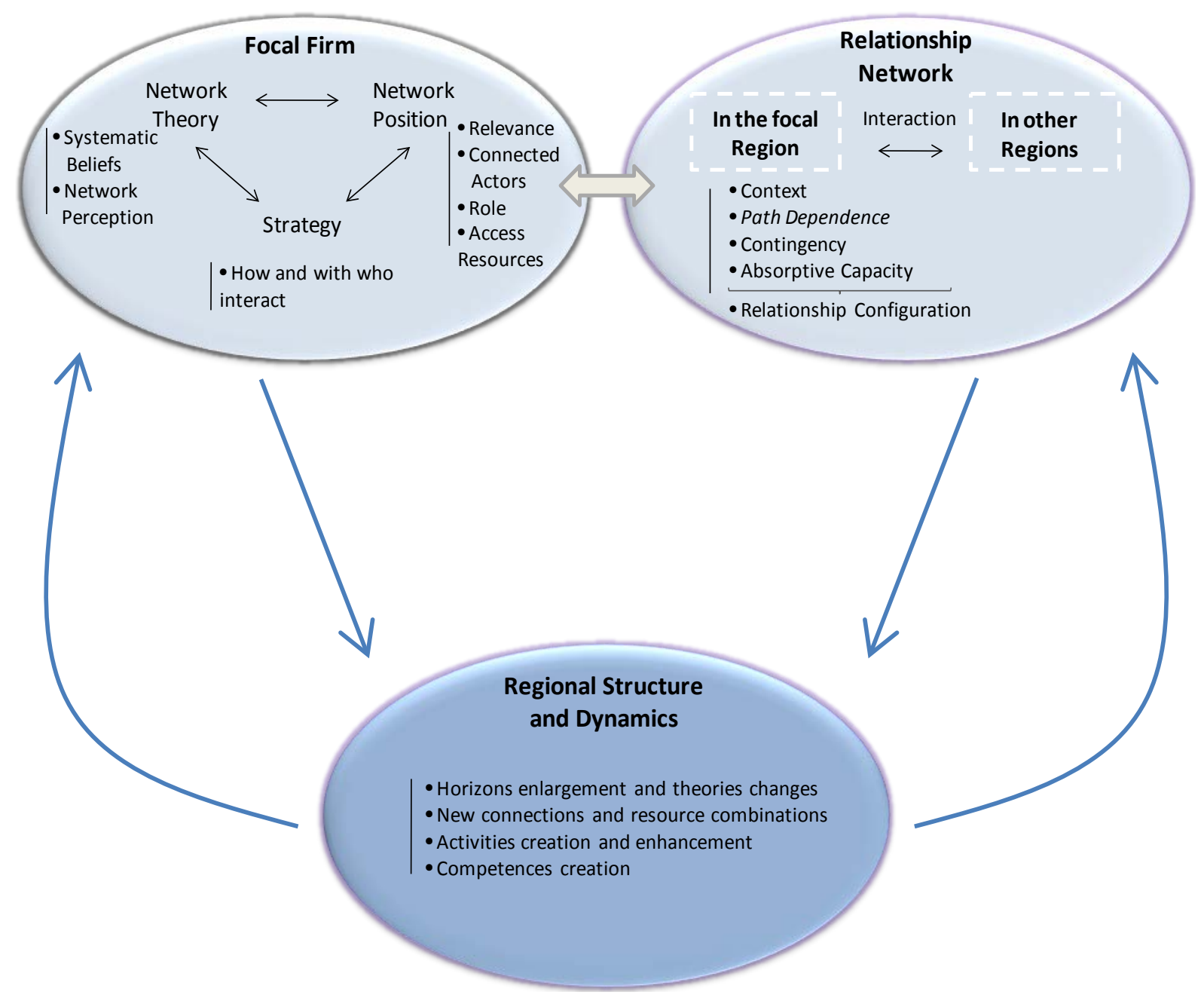

Figure 2. Conceptual model.

abiltiy [16] [62] [88] [108] [109].

Since these factors are quite specific, firms will have theories and occupy different positions in the network, therefore becoming factors leading to specific and strategic measures. Moreover they decisively influence the choice of counterparties with whom they relate and the mode of this relationship. Since firms clearly reveal themselves as selective in their relationships, there is a need for principles of action compatible with local firms. If not mere neighbourhood, far from leading to interaction, may lead to distance between the business actors. Thus, geographical proximity has a rather limited contribution to explain interactions. Local relationships are clearly dependent on the prior existence of counterparts evidencing some sort of similarity among their operating principles.

Counterparties are searched for at multiple scales visibly going beyond the local level. Still the relationships that firms develop locally are interconnected with others in different regions. Due to this connectivity, events in regions diverse from the focal one have the potential to alter the configuration of the relationships in the firm. Regional dynamics resulting from multiple interactions developed at different scales [7] [8] [19] [21] [24] [26] makes strategic action affect the dynamics of regions where the counterparties are located.

\subsubsection{Industrial Networks and Regions}

Firms which present principles of action and differential ways of relating among themselves, interact with the actors in the region where they are installed and with other regions where they extend its activity to, thus evidencing all the regions' particular characteristics. In fact, regions indexed to the location of the firms' present contexts, histories, contingency factors and an input capacity of different knowledges related to the firms [7] [8] 
[22] [23] [26] [32] [34] [36]. These characteristics may reveal different adequacy levels in relation to the specificity of the firms, thus conditioning the configuration of relationships and the influence they generate in the structure and dynamics of the region.

The firm's presence in the region, through the activity it performs, the available resources and the created relationships, is in continuous interaction with these regional characteristics. Depending on the features of both parties involved in this process, the interaction will have a greater or lesser ability to boost the structure and dynamics of the region.

Due to the interaction process with the focal firm, local actors can perceive new possibilities of interaction or ways of acting in the market, develop new activities, find new ways to combine their resources, relate with other actors in the network of the focal firm and internally create new competences [21] [24] [62] [70] [88] [111]. Each organisation can be seen as a specific combination of resources from a constellation existing in a certain region [21]. This constellation is dynamic and changes by the means of interaction [112]. The region is therefore understood as a constellation of resources which highlight the firms [21], and the occurrence of these effects will increase its dynamics and value. Though these possibilities depend on the characteristics of the interaction, the mere presence of a large firm is not sufficient to cause these effects, since they are dependent on the connections and requests made locally and on the local firms' capacity to respond to these stimuli [6] [113].

So, it can be stated that it is not enough to have a substantial number of local links to create regional dynamics. It is indeed essential that such links create competences that lead to the creation and rating of activities, which in turn originate new links and gather resources or contribute to a change in theories and a broader horizon for the interacting parts. Such effects depend, on a large scale, on the input capacity of each region. It is the interaction between the diverse organisational networks of the firms installed in a specific if region and the regional characteristics they possess that may create obstacles or advance the mentioned effects.

These relationships are necessarily connected, as part of various inter-organisational networks [114]. Changes in relationships lead to effects in the network [115] and any change in the way of coordinating activities and the use of resources will manifest itself on a larger scale [62]. Thus, any change in the local network relationships implies, via network, effects on other regions. The same applies to external links that inevitably reflect the firm in the region.

\subsubsection{Regional Structure and Dynamics}

The interaction developed by business organisations is a major factor affecting the network theory, being the firms the result of their relationships [17] [67] [88] [116]. Business organisations are evolutionary in their theories. Besides, the position they occupy in the network is dynamic and allocated by the counterparts with whom they relate. Thus, changes in the structure and regional dynamics resulting from multiple interactions can be reflected on the factors affecting the firm's strategic action and lead to a readjustment of its strategy, which through the influence of its network of relationships will have an effect on several scales. There is a clear pathway for this dynamic relationship between the firm and the region.

Likewise, the level of regional influence on the strategic action of firms is clear, their specificity reveals a vital role, so that they react differently to diverse regional characteristics. The same regional characteristics will interact with firms that have different conditioning elements of strategic action provoking different effects on each one of them. Thus, some physical or material characteristics of the region may be interpreted as limiting by certain firm which will be negatively influenced by them, and could be taken into account as a factor in stimulating innovation by others in order to overcome this constraint.

\section{Conclusions}

This paper encompasses a conceptual research with both theoretical and policy making contributions.

\subsection{Theoretical Contributions}

The process of relationship between relational geography and the industrial networks approach has strengthened the knowledge about the reciprocity between firms and regions. The detail of the firms organisation managed by its focus on the determinants of corporate strategy and in the interaction process that they develop, will overcome one of the major criticisms pointed at relational geography resulting from the fact that firms are simultaneously identified as a key element in regional dynamics, and nevertheless remain characterised in a both ge- 
neric and abstract way.

During this process, it is possible to understand the importance of subjective elements influencing the strategic performance of each firm's structure and dynamics in the region where it is located and in the others where they have influenced. This depends on the connectivity of their relationships and it is clear that the firms' connection to the region transcends material components, following from a meta-relational level that will determine the link between the various actors in the firm's network.

Firms are fairly diverse. Even within the same economic sector their performance is different and such diversity is reflected upon the way their relationship network articulates in various regions. Furthermore, regions are also fairly heterogeneous and have specific development paths and contexts that condition the firms' strategic action and relationships. Such specificity results in the fact that the same recipe cannot be used permanently to stimulate regional development. In this way, the relationship between firms and regions will always be specific and impossible to replicate. Therefore, there is no unique mechanism or generic law that explains the origin of a dynamic region. Such specificity renders the current literary trends which point to generic thesis of development based upon the combination of various material factors inside a geographically limited space as rather fragile.

The model developed based on relational geography trends and on the industrial network approach suggests that regional dynamics is mostly dependent on intangible factors and interaction processes at various scales. From a specific knowledge of a firm based on a specific relationship network, one can focus on the interaction of this network with the regional characteristics. Such an interaction can cause changes to the regional structure and dynamics. Besides, regions do not react in the same way to the firm's presence and the opportunities for regional dynamics that come with them. The larger regional effects do not happen by the merely physical presence of the firm but by the interactions and activations of competences in other actors it presence creates. Simultaneously, regional context does not influence firms to the same extent. Its specificity makes them interpret regional features in different ways and this reflects on a differentiated strategic performance.

\subsection{Contributions for Regional Policy}

This discussion results in some recommendations concerning regional policies. The essential question to solve by regional management is not subject to physical boundaries since all relationship networks may be connected to diverse regions. So, regional managers must enhance the firms' internal links as well as develop the links to external networks where they will garner several dynamic factors. In order to do so, they must create a great extent of knowledge about firms' specific needs and strategies. Such knowledge will allow for the identification of firms, which may be attractive and strategically compatible with organisational networks already established in a region. The knowledge of entrepreneurial actors will allow for the development of efforts by regional administration in order to make the relational distance between firms closer and more present in the same space, causing an increase in the possibilities of interaction.

Only a broad regional management understood as an intervention of local governing bodies in various geographical scales going beyond the limitation of its administrative power can identify the complementarities between existing skills and resources in different regions and then encourage the emergence of regional links through the interaction of their organisations and firms. Regions should have the clear perception that they are only one knot in a wide network of business relationships which occur at various scales. This knot will only gain prominence for the firm if it is considered crucial to create a certain value by having features unobtainable in other locations. These characteristics are often intangible assets arising from the action of various regional actors.

Despite the increasing knowledge in the interaction between firms and regions resulting from the complementarity between the Relational Geography and the Industrial Networks Approach, this process should be only the starting point for future work, which by using this complementarity enables the clarification of other process domains of the mutual influence between firms in the regions. For instance, the processes of relocating firms and the effect in terms of regional dynamics can be analysed in the light of the knowledge now generated. It can also be interesting to detail the influence of specific regional events on the relationship between firms. Likewise it is possible to understand the business group performance strategy framing it in terms of a region, definitively relating the firms’ specificity to geographic processes.

\section{References}

[1] Graham, S. and Healey, P. (1999) Relational Concepts of Space and Place: Issues for Planning Theory and Practice. 
European Planning Studies, 7, 623-646. http://dx.doi.org/10.1080/09654319908720542

[2] Dicken, P., et al. (2001) Chains and Networks, Territories and Scales: Towards a Relational Framework for Analysing the Global Economy. Global Networks, 1, 89-112. http://dx.doi.org/10.1111/1471-0374.00007

[3] Yeung, H.W.-C. (2005) The Firm as Social Networks: An Organisational Perspective. Growth \& Change, 36, 307-328. http://dx.doi.org/10.1111/j.1468-2257.2005.00279.x

[4] Dicken, P. and Malmberg, A. (2001) Firms in Territories: A Relational Perspective. Economic Geography, 77, 345363. http://dx.doi.org/10.2307/3594105

[5] Coe, N., et al. (2004) “Globalizing” Regional Development: A Global Production Networks Perspective. Transactions of the Institute of British Geographers, 29, 468-484. http://dx.doi.org/10.1111/j.0020-2754.2004.00142.x

[6] Henderson, J., et al. (2002) Global Production Networks and the Analysis of Economic Development. Review of International Political Economy, 9, 436-464. http://dx.doi.org/10.1080/09692290210150842

[7] Bathelt, H. (2006) Geographies of Production: Growth Regimes in Spatial Perspective 3-Toward a Relational View of Economic Action and Policy. Progress in Human Geography, 30, 223-236. http://dx.doi.org/10.1191/0309132506ph603pr

[8] Bathelt, H. and Glückler, J. (2003) Toward a Relational Economic Geography. Journal of Economic Geography, 3, 117-144. http://dx.doi.org/10.1093/jeg/3.2.117

[9] Coe, N., Dicken, P. and Hess, M. (2008) Global Production Networks: Realizing the Potential. Journal of Economic Geography, 8, 271-295. http://dx.doi.org/10.1093/jeg/lbn002

[10] Grabher, G. (2006) Trading Routes, Bypasses, and Risky Intersections: Mapping the Travels of "Networks" between Economic Sociology and Economic Geography. Progress in Human Geography, 30, 163-189. http://dx.doi.org/10.1191/0309132506ph600oa

[11] Murphy, J. (2003) Social Space and Industrial Development in East Africa: Deconstructing the Logics of Industry Networks in Mwanza, Tanzania. Journal of Economic Geography, 3, 173-198. http://dx.doi.org/10.1093/jeg/3.2.173

[12] Staber, U. (2001) The Structure of Networks in Industrial Districts. International Journal of Urban and Regional Research, 25, 537-552. http://dx.doi.org/10.1111/1468-2427.00328

[13] Glückler, J. (2007) Economic Geography and the Evolution of Networks. Journal of Economic Geography, 7, 619-634. http://dx.doi.org/10.1093/jeg/lbm023

[14] Ford, D. (1998) Two Decades of Interaction, Relationships and Networks. In: Naudé, P. and Turnbull, P., Eds., Network Dynamics in International Marketing, Pergamon, Oxford, 3-15.

[15] Ford, D., Häkansson, H. and Johanson, J. (1986) How Do Companies Interact? Industrial Marketing and Purchasing, 1, 26-41.

[16] Häkansson, H. and Snehota, I. (1995) Developing Relationships in Business Networks. Routledge, London.

[17] Turnbull, P., Ford, D. and Cunningham, M. (1996) Interaction, Relationships and Networks in Business Markets: An Evolving Perspective. Journal of Business \& Industrial Marketing, 11, 44-62. http://dx.doi.org/10.1108/08858629610125469

[18] Baraldi, E. (2006) The Places of Ikea: Using Space in Handling Resource Networks. In: Baraldi, E., Hjalmar, F. and Houltz, A., Eds., Taking Place: The Spatial Contexts of Science, Technology and Business, Science History Publications/USA, Sagamore Beach, 297-320.

[19] Baraldi, E. and Stromsten, T. (2006) Combining Scientific Knowledge and Venture Capital across Places and Networks of Resources. In: Houltz, A., Hjalmar, F. and Baraldi, E., Eds., Taking Place: The Spatial Contexts of Science, Technology and Business, Science History Publications/USA, Sagamore Beach, 247-273.

[20] Cova, B., Mazet, F. and Salle, R. (1996) Milieu as a Pertinent Unit of Analysis in Project Marketing. International Business Review, 5, 647-664. http://dx.doi.org/10.1016/S0969-5931(96)00032-7

[21] Häkansson, H., Tunisini, A. and Waluszewski, A. (2006) Place as a Resource in Business Networks. In: Houltz, A., Hjalmar, F. and Baraldi, E., Eds., Taking Place: The Spatial Contexts of Science, Technology and Business, Science History Publications/USA, Sagamore Beach, 223-246.

[22] Baraldi, E., Hjalmar, F. and Houltz, A. (2006) Taking Place: The Spatial Contexts of Science, Technology and Business. Science History Publications/USA, Sagamore Beach.

[23] Johnston, B. and Araújo, L. (2002) The Effects of Spatial Proximity on Inter-Organisational Relationships. 18th IMP Annual Conference, Dijon, 5-7 September 2002, 1-20.

[24] Mota, J. and Castro, L. (2004) Industrial Agglomerations as Localised Networks: The Case of the Portuguese Injection Mould Industry. Environment and Planning A, 36, 263-278. http://dx.doi.org/10.1068/a3684

[25] Lundberg, H. (2008) Geographical Proximity Effects and Regional Strategic Networks. Doctoral Thesis, Department 
of Business Studies, Uppsala University, Uppsala.

[26] Waluszewski, A. (2004) A Competing or Co-Operating Cluster or Seven Decades of Combinatory Resources? What's behind a Prospering Biotech Valley? Scandinavian Journal of Management, 20, 125-150. http://dx.doi.org/10.1016/j.scaman.2004.05.002

[27] Amin, A. (2004) Regions Unbound: Towards a New Politics of Place. Geografiska Annaler: Series B, Human Geography, 86, 33-44. http://dx.doi.org/10.1111/j.0435-3684.2004.00152.x

[28] Boggs, J. and Rantisi, N. (2003) The 'Relational Turn’ in Economic Geography. Journal of Economic Geography, 3, 109-116. http://dx.doi.org/10.1093/jeg/3.2.109

[29] Storper, M. (1997) Regional Economies as Relational Assets. In: Lee, R. and Wills, J., Eds., Geographies of Economics, Arnold, London, 248-258.

[30] Yeung, H.W.-C. (2005) Rethinking Relational Economic Geography. Transactions of the Institute of British Geographers, 30, 37-51. http://dx.doi.org/10.1111/j.1475-5661.2005.00150.x

[31] Ettlinger, N. (2003) Cultural Economic Geography and a Relational and Microspace Approach to Trusts, Rationalities, Networks, and Change in Collaborative Workplaces. Journal of Economic Geography, 3, 145-171. http://dx.doi.org/10.1093/jeg/3.2.145

[32] Amin, A. (1999) An Institutionalist Perspective on Regional Economic Development. International Journal of Urban and Regional Research, 23, 365-378. http://dx.doi.org/10.1111/1468-2427.00201

[33] Amin, A. and Thrift, N. (1994) Globalization, Institutions and Regional Development in Europe. Oxford University Press, Oxford.

[34] Lee, R. (2002) 'Nice Maps, Shame about the Theory’? Thinking Geographically about the Economic. Progress in Human Geography, 26, 333-355. http://dx.doi.org/10.1191/0309132502ph373ra

[35] Camagni, R. (2002) On the Concept of Territorial Competitiveness: Sound or Misleading? Urban Studies, 39, 23952411. http://dx.doi.org/10.1080/0042098022000027022

[36] Maskell, P. and Malmberg, A. (2007) Myopia, Knowledge Development and Cluster Evolution. Journal of Economic Geography, 7, 603-618. http://dx.doi.org/10.1093/jeg/lbm020

[37] Martin, R. and Sunley, P. (2003) Deconstructing Clusters: Chaotic Concept or Policy Panacea? Journal of Economic Geography, 3, 5-35. http://dx.doi.org/10.1093/jeg/3.1.5

[38] Taylor, M. and Asheim, B. (2001) The Concept of the Firm in Economic Geography. Economic Geography, 77, 315328. http://dx.doi.org/10.2307/3594103

[39] Schoenberger, E. (1999) The Firm in the Region and the Region in the Firm. In: Barnes, T. and Gertler, M., Eds., The New Industrial Geography: Regions, Regulation and Institutions, Routledge, London, 205-224.

[40] Giuliani, E. (2007) The Selective Nature of Knowledge Networks in Clusters: Evidence from the Wine Industry. Journal of Economic Geography, 7, 139-168. http://dx.doi.org/10.1093/jeg/lbl014

[41] Lee, C.-K. and Saxenian, A. (2008) Coevolution and Coordination: A Systemic Analysis of the Taiwanese Information Technology Industry. Journal of Economic Geography, 8, 157-180. http://dx.doi.org/10.1093/jeg/lbm049

[42] Amin, A. (1998) Globalisation and Regional Development: A Relational Perspective. Competition \& Change, 3, 145165.

[43] Howit, R. (2003) Scale. In: Agnew, J., Mitchell, K. and Toal, G., Eds., A Companion to Political Geography, Blackwell, Oxford, 138-157. http://dx.doi.org/10.1002/9780470998946.ch10

[44] Wolfe, D. and Gertler, M. (2004) Clusters from the Inside and Out: Local Dynamics and Global Linkages. Urban Studies, 41, 1071-1093. http://dx.doi.org/10.1080/00420980410001675832

[45] Bathelt, H. (2005) Cluster Relations in the Media Industry: Exploring the 'Distanced Neighbour' Paradox in Leipzig. Regional Studies, 39, 105-127. http://dx.doi.org/10.1080/0034340052000320860

[46] Sheppard, E. (2005) Positionality and Globalization in Economic Geography. In: Giovanna, V., Ed., The Changing Economic Geography of Globalization: Reinventing Space, Taylor \& Francis, Abingdon-on-Thames, 45-72.

[47] Yeung, H.W.-C. (2005) Organizational Space: A New Frontier in International Business Strategy? Critical Perspectives on International Business, 1, 219-240. http://dx.doi.org/10.1108/17422040510629728

[48] Amin, A. and Cohendet, P. (2005) Geographies of Knowledge Formation in Firms. Industry and Innovation, 12, 465486. http://dx.doi.org/10.1080/13662710500381658

[49] Smedlund, A. (2006) The Roles of Intermediaries in a Regional Knowledge System. Journal of Intellectual Capital, 7, 204-220. http://dx.doi.org/10.1108/14691930610661863

[50] Bathelt, H., Malmberg, A. and Maskell, P. (2004) Clusters and Knowledge: Local Buzz, Global Pipelines and the Process of Knowledge Creation. Progress in Human Geography, 28, 31-56. 
http://dx.doi.org/10.1191/0309132504ph469oa

[51] Owen-Smith, J. and Powell, W. (2002) Knowledge Networks in the Boston Biotechnology Community. Science as an Institution and the Institutions of Science, Siena.

[52] Camagni, R. (1991) Local 'Milieu', Uncertainty and Innovation Networks: Towards a New Dynamic Theory of Economic Space. In: Camagni, R., Ed., Innovation Networks: Spatial Perspectives, Belhaven, London, 121-144.

[53] Cohen, W. and Levinthal, D. (1989) Innovation and Learning: The Two Faces of R \& D. The Economic Journal, 99, 569-596. http://dx.doi.org/10.2307/2233763

[54] Cyert, R. and March, J. (1963) A Behavioral Theory of the Firm. Prentice-Hall, Englewood Cliffs.

[55] Katz, D. and Khan, R. (1966) The Social Psychology of Organizations. Wiley, New York.

[56] Pfeffer, J. and Salancik, G. (1978) The External Control of Organizations: A Resource Dependence Perspective. Harper \& Row, New York.

[57] Easton, G. and Araújo, L. (1989) The Network Approach: An Articulation. In: Johanson, J. and Hallen, L., Eds., Advances in International Marketing, Vol. 3, JAI Press, Greenwich, 97-119.

[58] Mattsson, L.-G. (1985) An Application of a Network Approach to Marketing: Defending and Changing Market Positions. In: Dholakia, N. and Arndt, J., Eds., Changing the Course of Marketing: Alternative Paradigms for Widening Market Theory (Supplement 2), JAI Press, Greenwich, 263-288.

[59] Häkansson, H. (1987) Industrial Technological Development. A Network Approach. Routledge, London.

[60] Achrol, R. (1991) Evolution of the Marketing Organization: New Forms for Turbulent Environments. Journal of Marketing, 55, 77-93. http://dx.doi.org/10.2307/1251958

[61] Nohria, N. and Eccles, R. (1992) Networks and Organizations: Structure, Form, and Action. Harvard Business School Press, Boston.

[62] Häkansson, H. and Waluszewski, A. (2002) Managing Technological Development. IKEA, the Environment and Technology. Routledge, London. http://dx.doi.org/10.4324/9780203217535

[63] Mattsson, L.-G. (2003) Reorganisation of Distribution in Globalisation of Markets: The Dynamic Context of Supply Chain Management. Supply Chain Management: An International Journal, 8, 416-426.

[64] Henneberg, S. and Mouzas, S. (2006) Network Pictures: Concepts and Representations. European Journal of Marketing, 40, 408-429. http://dx.doi.org/10.1108/03090560610648129

[65] Häkansson, H. (1982) International Marketing and Purchasing of Industrial Goods. Wiley, Chichester.

[66] Granovetter, M. (1985) Economic Action and Social Structure: The Problem of Embeddedness. American Journal of Sociology, 91, 481-510. http://dx.doi.org/10.1086/228311

[67] Snehota, I. (2004) Perspectives and Theories of Market. In: Hakansson, H., Harrison, D. and Waluszewski, A., Eds., Rethinking Marketing: Developing a New Understanding of Markets, Wiley, Chichester, 15-32.

[68] Häkansson, H., Virpi, H. and Pedersen, A.-C. (1999) Learning in Networks. Industrial Marketing Management, 28, 443-452. http://dx.doi.org/10.1016/S0019-8501(99)00080-2

[69] Wilkinson, I. and Young, L. (2007) Extending the Mind and Body of the Firm Through Global Partnerships. In: Aurifeille, J.-M., Svizzero, S. and Clement, A., Eds., Globalization and Partnerships: Features of Business Alliances and International Cooperation, Nova Publishers, New York, 39-46.

[70] Johnston, W., Peters, L. and Gassenheimer, J. (2006) Questions about Network Dynamics: Characteristics, Structures, and Interactions. Journal of Business Research, 59, 945-954. http://dx.doi.org/10.1016/j.jbusres.2006.03.002

[71] Ritter, T. and Ford, D. (2004) Interactions between Suppliers and Customers in Business Markets. In: Häkansson, H., Harrison, D. and Waluszewski, A., Eds., Rethinking Marketing-Developing a New Understanding of Markets, Wiley, London, 99-115.

[72] Walter, A., Ritter, T. and Gemunden, H. (2001) Value-Creation in Buyer-Seller Relationships: Theoretical Considerations and Empirical Results from a Supplier's Perspective. Industrial Marketing Management, 30, 365-377. http://dx.doi.org/10.1016/S0019-8501(01)00156-0

[73] Astley, W. (1984) Toward an Appreciation of Collective Strategy. Academy of Management Review, 9, 526-535.

[74] Häkansson, H. and Snehota, I. (1989) No Business Is an Island. Scandinavian Journal of Management, 5, 187-200.

[75] Thorelli, H. (1986) Networks: Between Markets and Hierarchies. Strategic Management Journal, 7, 37-51. http://dx.doi.org/10.1002/smj.4250070105

[76] Huemer, L., Becerra, M. and Lunnan, R. (2004) Organizational Identity and Network Identification: Relating within and beyond Imaginary Boundaries. Scandinavian Journal of Management, 20, 53-73. http://dx.doi.org/10.1016/j.scaman.2004.05.003 
[77] Baraldi, E., Brennan, R., Harrison, D., Tunisini, A. and Zolkiewski, J. (2007) Strategic Thinking and the IMP Approach: A Comparative Analysis. Industrial Marketing Management, 36, 879-894. http://dx.doi.org/10.1016/j.indmarman.2007.05.015

[78] Easton, G. and Häkansson, H. (1996) Markets as Networks: Editorial Introduction. International Journal of Research in Marketing, 13, 407-413. http://dx.doi.org/10.1016/S0167-8116(96)00027-4

[79] Anderson, J., Häkansson, H. and Johanson, J. (1994) Dyadic Business Relationships within a Business Network Context. Journal of Marketing, 58, 1-15.

[80] Ford, D. and Häkansson, H. (2006) IMP—Some Things Achieved: Much More to Do. European Journal of Marketing, 40, 248-258. http://dx.doi.org/10.1108/03090560610648039

[81] Snehota, I. (1990) Notes on a Theory of Business Enterprise. Ph.D. Thesis, Uppsala University, Uppsala.

[82] Badaracco, J. (1991) The Boundaries of the Firm. In: Etzioni, A. and Lawrence, P., Eds., Socioeconomics: Towards a New Synthesis, M.E. Sharpe, New York, 293-327.

[83] Jüttner, U. and Schlange, L. (1996) A Network Approach to Strategy. International Journal of Research in Marketing, 13, 479-494. http://dx.doi.org/10.1016/S0167-8116(96)00025-0

[84] Holmen, E. and Pedersen, A.-C. (2003) Strategizing through Analyzing and Influencing the Network Horizon. Industrial Marketing Management, 32, 409-418. http://dx.doi.org/10.1016/S0019-8501(03)00014-2

[85] Ford, D. and Häkansson, H. (2006) The Idea of Business Interaction. IMP Journal, 1, 4-20.

[86] Johanson, J. and Mattsson, L. (1992) Network Positions and Strategic Actions-An Analytical Framework. In: Axelsson, B. and Easton, G., Eds., Industrial Networks: A New View of Reality, Routledge, London, 205-217.

[87] Axelsson, B. (1992) Corporate Strategy Models and Networks. In: Axelsson, B. and Easton, G., Eds., Industrial Networks: A New View of Reality, Routledge, London, 184-201.

[88] Wilkinson, I. and Young, L. (2002) On Cooperating: Firms, Relations and Networks. Journal of Business Research, 55, 123-132. http://dx.doi.org/10.1016/S0148-2963(00)00147-8

[89] Duysters, G., Man, A.-P. and Wildeman, L. (1999) A Network Approach to Alliance Management. European Management Journal, 17, 182-187. http://dx.doi.org/10.1016/S0263-2373(98)00077-2

[90] Low, B. (1997) Managing Business Relationships and Positions in Industrial Networks. Industrial Marketing Management, 26, 189-202. http://dx.doi.org/10.1016/S0019-8501(96)00091-0

[91] Henders, B. (1992) Positions in Industrial Networks, Marketing Newsprint in the UK. Ph.D. Thesis, Department of Business Studies, Uppsala University, Uppsala.

[92] Johanson, J. and Mattsson, L.-G. (1985) Marketing Investments and Market Investments in Industrial Networks. International Journal of Research in Marketing, 2, 185-195. http://dx.doi.org/10.1016/0167-8116(85)90011-4

[93] Brito, C. (2001) Towards an Institutional Theory of the Dynamics of Industrial Networks. Journal of Business \& Industrial Marketing, 16, 150-166. http://dx.doi.org/10.1108/08858620110389777

[94] Welch, C. and Wilkinson, I. (2002) Idea Logics and Network Theory in Business Marketing. Journal of Business to Business Marketing, 9, 27-48. http://dx.doi.org/10.1300/J033v09n03_02

[95] Ford, D., et al. (2002) Managing Networks. 18th Industrial Marketing and Purchasing Group Conference, Perth, 11-13 December 2002.

[96] Mason, K. and Mouzas, S. (2007) Framing Business Relationships: The Role of Business Models. 23rd IMP Annual Conference, Manchester, 30 August-1 September 2007.

[97] Holmen, E., Häkansson, H. and Pedersen, A.-C. (2003) Framing as a Means to Manage a Supply Network. Journal of Customer Behaviour, 2, 385-407.

[98] Amit, R. and Schoemaker, P. (1993) Strategic Assets and Organizational Rent. Strategic Management Journal, 14, 3346. http://dx.doi.org/10.1002/smj.4250140105

[99] Barney, J. (1991) Firm Resources and Sustained Competitive Advantage. Journal of Management, 17, 99-120. http://dx.doi.org/10.1177/014920639101700108

[100] Peteraf, M. (1993) The Cornerstones of Competitive Advantage: A Resource-Based View. Strategic Management Journal, 14, 179-191. http://dx.doi.org/10.1002/smj.4250140303

[101] Conner, K. (1991) A Historical Comparison of Resource-Based Theory and Five Schools of Thought within Industrial Organization Economics: Do We Have a New Theory of the Firm? Journal of Management, 17, 121-154. http://dx.doi.org/10.1177/014920639101700109

[102] Penrose, E. (1959) The Theory of the Growth of the Firm. Basil Blackwell, Oxford.

[103] Richardson, B. (1972) The Organisation of Industry. The Economic Journal, 82, 883-896. 
http://dx.doi.org/10.2307/2230256

[104] Loasby, B. (1998) The Concept of Capabilities. In: Foss, N. and Loasby, B., Eds., Economic Organization, Capabilities and Coordination: Essays in Honour of G.B. Richardson, Routledge, London, 163-182.

[105] Loasby, B. (1998) The Organization of Capabilities. Journal of Behaviour and Organization, 35, 139-160. http://dx.doi.org/10.1016/S0167-2681(98)00056-0

[106] Araújo, L., Dubois, A. and Gadde, L.-E. (1999) Managing Interfaces with Suppliers. Industrial Marketing Management, 28, 497-506. http://dx.doi.org/10.1016/S0019-8501(99)00077-2

[107] Gadde, L.-E., Huemer, L. and Häkansson, H. (2003) Strategizing in Industrial Networks. Industrial Marketing Management, 32, 357-364. http://dx.doi.org/10.1016/S0019-8501(03)00009-9

[108] Araújo, L., Dubois, A. and Gadde, L.-E. (2003) The Multiple Boundaries of the Firm. Journal of Management Studies, 40, 1255-1277. http://dx.doi.org/10.1111/1467-6486.00379

[109] Gulati, R. (1999) Network Location and Learning: The Influence of Network Resources and Firm Capabilities on Alliance Formation. Strategic Management Journal, 20, 397-420. http://dx.doi.org/10.1002/(SICI)1097-0266(199905)20:5<397::AID-SMJ35>3.0.CO;2-K

[110] Ford, D. (2002) The Development of Buyer-Seller Relationships in Industrial Markets. Thomson Learning, London.

[111] Ritter, T., Wilkinson, I. and Johnston, W. (2004) Managing in Complex Business Networks. Industrial Marketing Management, 33, 175-183. http://dx.doi.org/10.1016/j.indmarman.2003.10.016

[112] Waluszewski, A., et al. (2008) Analysing Business Interaction. 24th IMP Conference, Uppsala, 4-6 September 2008, $1-37$.

[113] Cohen, W. and Levinthal, D. (1990) Absorptive Capacity: A New Perspective on Learning and Innovation. Administrative Science Quarterly, 35, 128-152. http://dx.doi.org/10.2307/2393553

[114] Mattsson, L.-G. (2004) Industrial Marketing the Network Perspective. In: Backhaus, K. and Voeth, M., Eds., Handbuch Industriegüter Marketing, Gabler Verlag, Wiesbaden, 175-201. http://dx.doi.org/10.1007/978-3-322-91260-2 7

[115] Hadjikhani, A. and Thilenius, P. (2005) The Impact of Horizontal and Vertical Connections on Relationships' Commitment and Trust. Journal of Business \& Industrial Marketing, 20, 136-147. http://dx.doi.org/10.1108/08858620510592759

[116] Häkansson, H. and Ford, D. (2002) How Should Companies Interact in Business Networks? Journal of Business Research, 55, 133-139. http://dx.doi.org/10.1016/S0148-2963(00)00148-X

\section{Submit or recommend next manuscript to SCIRP and we will provide best service for you:}

Accepting pre-submission inquiries through Email, Facebook, LinkedIn, Twitter, etc.

A wide selection of journals (inclusive of 9 subjects, more than 200 journals)

Providing 24-hour high-quality service

User-friendly online submission system

Fair and swift peer-review system

Efficient typesetting and proofreading procedure

Display of the result of downloads and visits, as well as the number of cited articles

Maximum dissemination of your research work

Submit your manuscript at: http://papersubmission.scirp.org/ 